\title{
Integral clinical and neuroimaging criteria for the prognosis of spontaneous supratentorial intracerebral hemorrhage acute period outcome
}

\author{
A. A. Kuznietsov \\ Zaporizhzhia State Medical University, Ukraine
}

Key words:

cerebral

hemorrhage,

X-Ray tomography,

prognosis.

\section{Zaporozhye}

medical journal

2018; 20 (2), 152-156

DOl:

10.14739/2310-1210

2018.2.124820

E-mail:

titus3.05@gmail.com
The purpose of this study was to develop integrated clinical and neuroimaging criteria for the prediction of spontaneous supratentorial intracerebral hemorrhage (SSICH) acute period outcome.

Materials and methods. Complex clinical and neuroimaging study was conducted in 105 patients (56 men and 49 women, mean age $63.6 \pm 1.2$ years) with $\mathrm{SSICH}$ in acute period of the disease receiving conservative therapy. The examination included computer tomography of the brain and clinical assessment using National Institute of Health Stroke Scale (NIHSS), Glasgow Coma Scale (GCS). The disability level was detected in accordance with the modified Rankine Scale (mRS) on the 21 st day of the disease.

Results. Lethal outcome (21.9\%), unfavourable functional outcome in the form of $4-5$ points in accordance with the mRS ( $33.4 \%$ ) and favourable functional outcome in the form of $\leq 3$ points in accordance with the aforementioned scale on the 21 st day of SSICH $(45.7 \%)$ were registered. The mathematical model has been elaborated for the prediction of lethal outcome of SSICH acute period, which takes into account the initial level of neurological deficit in accordance with NIHSS, the lesion volume and septum pellucidum displacement at the onset of the disease (AUC $=0.91(0.84-0.96), \mathrm{P}<0.01$ ). The mathematical model has been elaborated for the prediction of functional outcome of SSICH acute period, which takes into account the patient's age, the level of neurological deficit in accordance with NIHSS, the lesion volume at the onset of the disease (AUC $=0.89(0.80-0.95), P<0.01$ ).

Conclusions. Integral clinical and neuroimaging predictors of the lethal outcome of SSICH acute period $(\mathrm{Se}=91.3 \%$; $\mathrm{Sp}=82.9 \%$; accuracy of prediction $=85.7 \%)$ and $\mathrm{mRS}$ score $\leq 3$ on the 21 st day of the disease $(\mathrm{Se}=85.4 \% ; \mathrm{Sp}=82.4 \%$; accuracy of prediction $=80.5 \%$ ) were determined.
Кнючові слова: внутрішньомозковий крововилив, комп'ютерна томографія, прогноз.

Запорізький медичний журнал. - 2018. T. 20, № 2(107). C. $152-156$

Інтегральні киініко-нейровізуалізаційні критерії прогнозування наслідків гострого періоду спонтанного супратенторіального внутрішньомозкового крововияиву

\section{А. А. Кузнєцов}

Мета роботи - розробка інтегральних клініко-нейровізуалізаційних критеріїв прогнозування наслідків гострого періоду спонтанного супратенторіального внутрішньомозкового крововиливу (ССВМК).

Матеріали та методи. Проведено комплексне клініко-нейровізуалізаційне дослідження 105 пацієнтів (56 чоловіків і 49 жінок, середній вік - 63,6 1 1,2 року) в гострому періоді ССВМК на тлі консервативної терапії. Дослідження включало комп'ютерну томографію головного мозку та оцінювання за шкалою інсульту Національного інституту здоров'я США (NIHSS), Шкалою коми Глазго (GCS). Рівень інвалідизації оцінювали на 21 добу захворювання за модиффікованою шкалою Ренкіна (МШР).

Результати. У структурі наслідків гострого періоду ССВМК зареєстрували летальний результат (21,9%), несприятливий функціональний вихід у формі значення 4-5 балів за шкалою Ренкіна (33,4 \%) та сприятливий функціональний вихід у формі значення $\leq 3$ бали за названою шкалою на 21 добу захворювання $(45,7 \%)$. Розроблено математичну модель для прогнозування летального виходу гострого періоду ССВМК, що враховує вихідний рівень неврологічного дефіциту за NIHSS, обсяг осередку ураження та зміщення прозорої перетинки в дебюті захворювання (AUC = 0,91 $(0,84-0,96)$, $\mathrm{p}<0,01)$. Розроблено математичну модель для прогнозування функціонального виходу гострого періоду ССВМК, що враховує вік пацієнта, рівень неврологічного дефріциту за NIHSS, обсяг осередку ураження в дебюті захворювання $(A \cup C=0,89(0,80-0,95), p<0,01)$.

Висновки. Розроблено інтегральні клініко-нейровізуалізаційні предиктори летального результату гострого періоду ССВМК (чутливість = 91,3 \%; специфрічність = 82,9 \%; точність прогнозування $=85,7 \%$ ) і значення $\leq 3$ бали за МШР на 21 добу захворювання (чутливість $=85,4$ \%; специфрічність $=82,4 \%$; точність прогнозування = 80,5 \%).

Ключевые слова: внутримозговое кровоизиияние, компьютерная томография, прогноз.

\footnotetext{
Запорожский медицинский журнал. - 2018. -

T. 20, № 2(107). -

C. $152-156$
}

\section{Интегральные киинико-нейровизуализационные критерии прогнозирования исхода острого периода спонтанного супратенториального внутримозгового кровоизлияния}

\section{А. А. Кузнецов}

Цель работы - разработка интегральных клинико-нейровизуализационных критериев прогнозирования исхода острого периода спонтанного супратенториального внутримозгового кровоизлияния (ССВМК)

Материалы и методы. Проведено комплексное клинико-нейровизуализационное исследование 105 пациентов (56 мужчин и 49 женщин, средний возраст - 63,6 \pm 1,2 года) в остром периоде ССВМК на фоне консервативной терапии. Исследование включало компьютерную томографию головного мозга и оценку по Шкале инсульта Нацио- 
нального института здоровья США (NIHSS), Шкале комы Глазго (GCS). Уровень инвалидизации оценивали на 21 сутки заболевания по модифицированной шкале Рэнкина (мШР).

Результаты. В структуре исходов острого периода ССВМК зарегистрировали летальный исход (21,9 \%), неблагоприятный функциональный исход в форме значения 4-5 баллов по шкале Рэнкина (33,4 \%) и благоприятный функциональный исход в форме значения $\leq 3$ балла по указанной шкале на 21 сутки заболевания (45,7 \%). Разработана математическая модель для прогнозирования летального исхода острого периода ССВМК, которая учитывает исходный уровень неврологического дефицита по NIHSS, объем очага поражения и смещение прозрачной перегородки в дебюте заболевания (AUC = 0,91 (0,84-0,96), $\mathrm{p}<0,01)$. Разработана математическая модель для прогнозирования функционального исхода острого периода ССВМК, которая учитывает возраст пациента, уровень неврологического десрицита по NIHSS, объем очага поражения в дебюте заболевания (AUC = 0,89 $(0,80-0,95), p<0,01$ ).

Выводы. Разработаны интегральные клинико-нейровизуализационные предикторы летального исхода острого периода ССВМК (чувствительность = 91,3\%; специфичность $=82,9 \%$; точность прогнозирования $=85,7 \%$ ) и значения $\leq 3$ балла по МШР на 21 сутки заболевания (чувствительность = 85,4 \%; специфичность = 82,4 \%; точность прогнозирования $=80,5 \%)$.

\section{Introduction}

In spite of the significant progress in fundamental sciences and clinical vascular neurology, cerebral hemorrhagic stroke and its most common form - spontaneous supratentorial intracerebral hemorrhage (SSICH) continues to be one of the most significant and, unfortunately, still unresolved medical and social problems of our time, taking leading positions in the structure of death and disability of the adult population in most countries of the world [7,11].

At the present day there is no doubt in the significance of individual vital and functional prognosis verification that are among the reasons for the differentiated choice of tactics in the acute period of SSICH $[1,2,5]$. Numerous studies have convincingly proved the relationship between the initial neurological deficiency level, lesion volume, the dislocation syndrome severity with the disease outcome $[4,9,10]$. Moreover, informative criteria for the prediction of $\mathrm{SSICH}$ acute period outcome, which would take into consideration the clinical and neurological symptomatology and the results of CT scan of brain at the onset of disease, are not currently available [6].

\section{Purpose}

Purpose of this study was to develop integrated clinical and neuroimaging criteria for the prediction of $\mathrm{SSICH}$ acute period outcome.

\section{Materials and methods}

Complex clinical and paraclinical study was conducted in 105 patients (56 men and 49 women, mean age $63.6 \pm 1.2$ years) with $\mathrm{SSICH}$. They were hospitalized within the first 24 hours since the onset of the disease and received conservative therapy at Brain Circulation Disorders Department of the Municipal Institution "City Clinical Hospital No. 6". The study excluded patients who had acute disorders of cerebral circulation in the anamnesis, oncological and/or decompensated somatic pathology. The cases of extracerebral cause of death in accordance with the autopsy results were also excluded.

The following results were taken into consideration: the results of clinical and neurological study with the initial levels of neurologic deficit assessment in accordance with the National Institute of Health Stroke Scale (NIHSS) and level of consciousness assessment in accordance with the Glasgow Coma Scale (GCS), as well as the disability level in accordance with the modified Rankine Scale (mRS) on the 21st day of the disease. Herewith, in accordance with this scale, the value of $\leq 3$ points were considered as a favourable functional outcome. Computed Tomography (CT) Scanner "Siemens Somatom Spirit" was used for neuroimaging investigation of the brain. The following results of CT scan of the brain were analysed lesion volume, severity of dislocation syndrome due to median brain structures displacement, presence of blood breakthrough into the ventricular system of the brain. Hemphill-ICH Scale and ICH-GS were used for complex clinical and neuroimaging assessment of patient status severity at the onset of SSICH.

The statistical data processing was carried out with the help of Statistica 6.0 software (StatSoft Inc., USA, series number AXXR712D833214FAN5) and MedCalc (version 16.4) using nonparametric analysis of variance, binary logistic regression and ROC analysis.

\section{Results and discussion}

Lethal outcome (21.9\%), unfavourable functional outcome in the form of 4-5 points in accordance with the mRS $(33.4 \%)$ and favourable functional outcome in the form of $\leq 3$ points in accordance with the aforementioned scale on the 21 st day of SSICH (45.7\%) were registered in the outcome structure in the acute period of the disease.

On the basis of nonparametric analysis of variance it has been determined that patients with lethal outcome of SSICH acute period had a higher level of neurologic deficit in accordance with the NIHSS, a more pronounced cerebral syndrome in accordance with the GCS as well as a bigger lesion volume and more pronounced indexes (Table 1).

The following multivariant mathematical model in the form of binary logistic regression equation was elaborated within the informative criteria study for the $\mathrm{SSICH}$ acute period outcome prediction:

$$
\begin{aligned}
& \beta 1=0.122 \times \mathrm{P} 1+0.021 \times \mathrm{P} 2+0.118 \times \mathrm{P} 3-4.52 \\
& 4.52 \text { - intercept }(\beta 0) ; \\
& \mathrm{P} 1 \text { - NIHSS score on admission; } \\
& \mathrm{P} 2 \text { - lesion volume on admission }(\mathrm{ml}) ; \\
& \mathrm{P} 3 \text { - septum pellucidum displacement on admission, }
\end{aligned}
$$
$\mathrm{mm}$.

The approximation accuracy of interrelation between 
Table 1. Analysis of clinical and neurological data and the results of CT brain scan at the onset of SSICH in comparison with the acute period outcome, Me (Q1; Q3)

\begin{tabular}{llll}
\hline Indexes & $\begin{array}{l}\text { Lethal outcome } \\
(\mathbf{n}=\mathbf{2 3})\end{array}$ & $\begin{array}{l}\text { Non-lethal outcome } \\
(\mathbf{n}=\mathbf{8 2})\end{array}$ & $\mathbf{P}$ \\
\hline Age, years & $62.0(52.0-75.5)$ & $63.5(57.0-75.0)$ & 0.9356 \\
NIHSS score on the $1^{\text {st }}$ day & $22.0(16.0-28.0)$ & $9.0(5.0-15.0)$ & $<0.0001$ \\
GCS score on the $1^{\text {st }}$ day & $10.0(5.0-13.0)$ & $15.0(13.0-15.0)$ & $<0.0001$ \\
Lesion volume, $\mathrm{ml}$ & $58.7(29.2-89.8)$ & $11.2(3.2-24.5)$ & $<0.0001$ \\
Septum pellucidum displacement, $\mathrm{mm}$ & $10.0(4.5-12.0)$ & $1.0(0.0-4.8)$ & $<0.0001$ \\
Pineal gland displacement, mm & $5.0(2.5-10.5)$ & $1.0(0.0-4.0)$ & $<0.0001$ \\
\hline
\end{tabular}

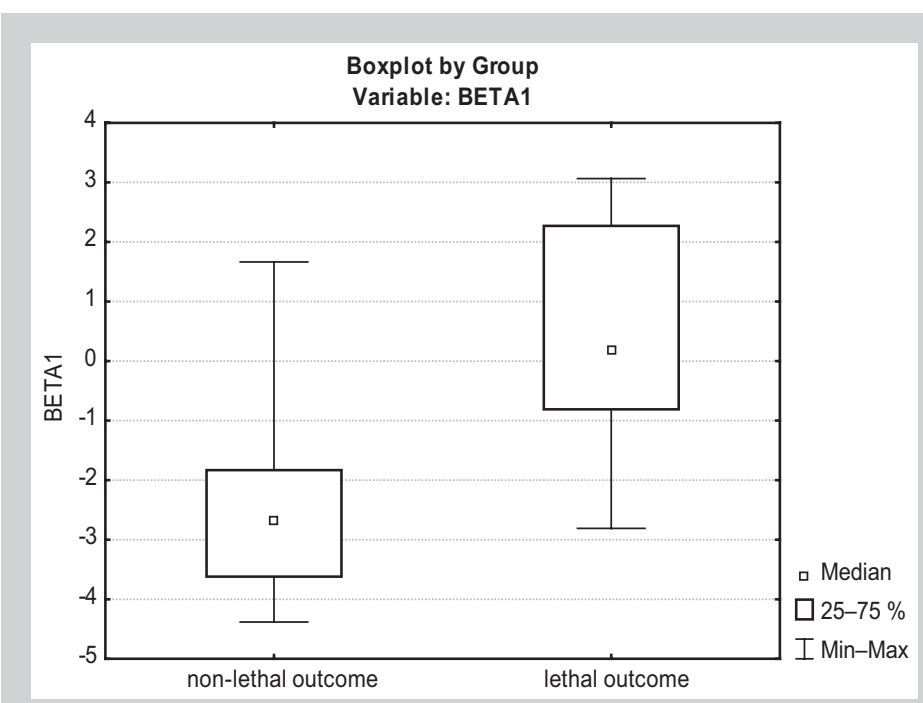

Fig. 1. $\beta 1$ index level in comparison with SSICH acute period outcome.

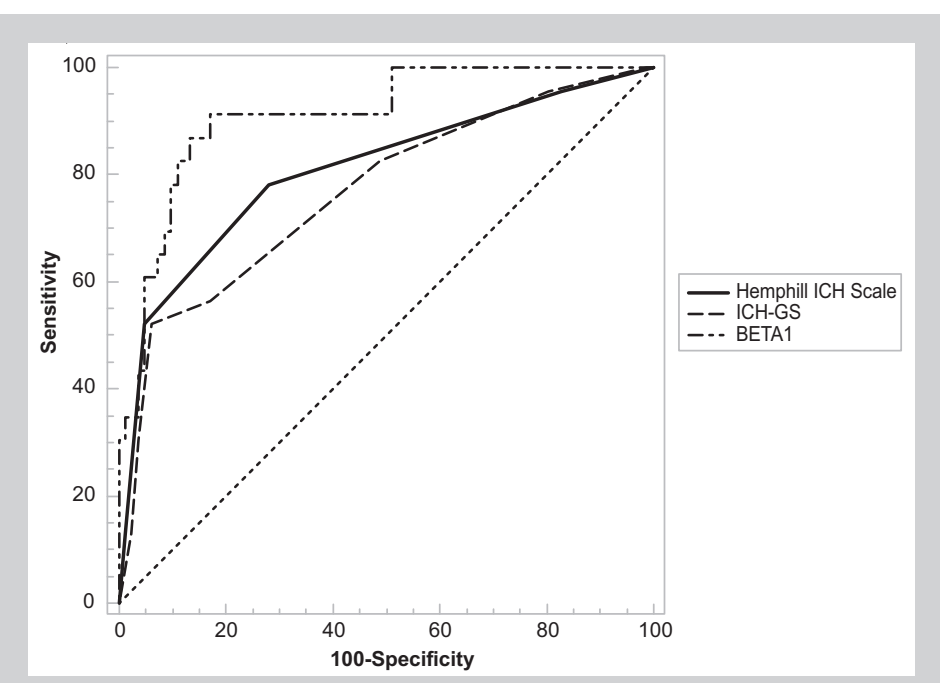

Fig. 2. Results of the comparative ROC-analysis in relation to the informative value of Hemphill-ICH Scale, ICH-GS assessment and the elaborated mathematical model for spontaneous supratentorial intracerebral hemorrhage acute period lethal outcome prediction.

predictors and dependent variable constituted $85.7 \%$ (Chisquare $=44.562, \mathrm{P}<0.0001 ;$ Hosmer \& Lemeshow test $\mathrm{P}=0.29 ; \mathrm{AUC}=0.91$ (0.84-0.96), $\mathrm{P}<0.01)$.

Patients with lethal outcome of SSICH acute period showed higher indexes of $\beta 1(P<0.01)$ at the onset of disease (Fig. 1).

On the basis of the ROC analysis it has been determined that the value $\beta 1>-1.68$ was an integral predictor of $\mathrm{SSICH}$ acute period lethal outcome with sensitivity levels $91.3 \%$ and specificity levels $82.9 \%$.

The lethal outcome rate constituted $60.0 \%$ in the group of patients having a value of $\beta 1>-1.68(n=35)$, while it constituted $2.9 \%(R R=21,0(5.2-84.5), P<0.01)$ in patients with a value of $\beta 1 \leq-1.68(n=70)$.

Thus, the value of $\beta 1>-1.68$ appears to be an integral clinical and neuroimaging factor of an unfavorable vital prognosis, being associated with an increase of $\mathrm{SSICH}$ acute period lethal outcome risk by 21 times.

On the basis of the comparative ROC analysis, it has been determined that the elaborated mathematical model (AUC $=0.91$ (0.84-0.96)) had a higher informative value in comparison with the Hemphill-ICH Scale (AUC $=0.81$ (0.72-0.88), $\mathrm{P}<0.01)$ and ICH-GS (AUC $=0.77(0.68-$ $0.85), \mathrm{P}<0.01)$ as for individual vital prognosis of $\mathrm{SSICH}$ acute period outcome determination (Fig. 2).

On the basis of a non-parametric dispersion analysis, it has been determined that patients with an unfavorable functional outcome of SSICH acute period revealed the following indexes at the onset of disease in terms of the following criteria: age, NIHSS neurologic deficit, GCS scores, pineal gland and septum pellucidum displacement degree (Table 2).

The following multivariant mathematical model in the form of the binary logistic regression equation was elaborated for the prognosis of the functional outcome of SSICH acute period:

$$
\beta 2=7.41-0.06 \times \mathrm{P} 1-0.252 \times \mathrm{P} 2-0.027 \times \mathrm{P} 3
$$

$$
\begin{aligned}
& 7.41 \text { - intercept ( } \beta 0) \text {; } \\
& \text { P1 - age (years); } \\
& \text { P2 - NIHSS score on admission; } \\
& \text { P3 - lesion volume on admission (ml). }
\end{aligned}
$$

The approximation accuracy of the functional prognosis with the help of present model constituted $80.5 \%$ (Chisquare $=40.33, P<0.0001 ;$ Hosmer \& Lemeshow test $\mathrm{P}=0.88 ; \mathrm{AUC}=0.89(0.80-0.95), \mathrm{P}<0.01)$.

Patients with favourable functional outcome of $\mathrm{SSICH}$ acute period at the onset of disease showed higher indexes of $\beta 2(P<0.01)$ (Fig. 3).

On the basis of the ROC analysis, it has been determined that the value $\beta 2>0.188$ was the integral criterion of a favorable functional outcome of SSICH acute period with sensitivity levels $85.4 \%$ and specificity levels $82.4 \%$.

In the group of patients with a value of $\beta 2>0.188$ $(n=47)$, the frequency of a favorable functional outcome constituted $87.2 \%$, in patients with a value of $\beta 2 \leq 0.188$ $(n=35)-20.0 \%(R R=4.4(3.8-5.0), P<0.01)$.

Thus, the value $\beta 2>0.188$ can be fairly associated with the mRS score $\leq 3$ on the 21 st day of $\mathrm{SSICH}$ and it appears to be an integral clinical and neuroimaging factor for a favorable functional prognosis of $\mathrm{SSICH}$ acute period outcome.

On the basis of the comparative ROC-analysis, it has been determined that the elaborated mathematical model (AUC $=0.89(0.80-0.94))$ had a higher informative value in comparison with Hemphill-ICH Scale (AUC $=0.71(0.60$ $0.80), \mathrm{P}<0.01)$ and ICH-GS (AUC = $0.75(0.64-0.84)$, $\mathrm{P}<0.01$ ) for individual functional prognosis of $\mathrm{SSICH}$ acute period outcome determination (Fig. 4). 
Thus, the study made it possible to develop multivariant mathematical models in the form of binary logistic regression equations for the SSICH acute period outcome prediction. Herewith, the combination of neurological deficit level, lesion volume and septum pellucidum displacement at the onset of disease appeared to be the most informative criteria for the lethal outcome of SSICH acute period prediction, while the degree of functional recovery on the $21^{\text {st }}$ day of $\mathrm{SSICH}$ was determined by the neurological deficit and lesion volume at the onset of the disease, as well as by the patient's age. The neurological deficit presence and the lesion volume in both mathematical models are consistent with the results of other studies, which proved the interrelation between clinical and neuroimaging criteria for brain damage degree due to $\mathrm{SSICH}$ and the disease acute period outcome assessment $[3,9,10]$. The presence of septum pellucidum displacement as part of a mathematical model for the vital prognosis determination confirms the leading role of the dislocation syndrome, caused by SSICH volume combined with perifocal edema, in the progredient course of disease acute period [8].

In the course of the study the values of binary logistic regression equations were determined, namely, the values which appear to be highly sensitive and highly specific, integrated clinical and neuroimaging prognostic criteria that take into account the complex of clinical and neurological data and the results of CT brain scan at the onset of disease. On the basis of the comparative analysis of AUC values results the elaborated mathematical models had a higher predictive accuracy than both Hemphill-ICH Scale and ICH-GS, which justifies their rational use in routine clinical practice as tools for the individual vital and functional outcome prognosis and in choosing optimal therapeutic tactics at the onset of disease. Level $\beta 1>-1.68$ defines the vital prognosis as unfavorable. It is necessary to determine the functional prognosis on the basis of $\beta 2$ level assessment in patients who have level $\beta 1 \leq-1.68$ and a favorable vital prognosis. The functional prognosis is defined as favorable if level $\beta 2>0.175$, while $\beta 2 \leq 0.175$ - as unfavorable.

\section{Conclusions}

1. The mathematical model was elaborated for the prediction of the lethal outcome of SSICH acute period, which takes into account the initial level of neurological deficit in accordance with NIHSS, the lesion volume and septum pellucidum displacement at the onset of the disease (AUC $=0.91(0.84-0.96))$ and it has a higher informative value than both Hemphill-ICH Scale (AUC $=0.81(0.72$ $0.88), P<0.01)$ and ICH-GS (AUC $=0.77(0.68-0.85)$, $P<0.01)$ for the individual vital prognosis, while the index $\beta 1>-1.68$ is the integral predictor of the lethal outcome of $\mathrm{SSICH}$ acute period $(\mathrm{Se}=91.3 \%$; $\mathrm{Sp}=82.9 \%$; accuracy of prediction $=85.7 \%$ ).

2. The mathematical model was elaborated for the prediction of the functional outcome of SSICH acute period, which takes into account the age of the patient, the level of neurological deficit in accordance with NIHSS, the lesion volume at the onset of the disease (AUC $=0.89$ $(0.80-0.95))$ and has a higher informative value than both Hemphill-ICH Scale (AUC $=0.71(0.60-0.80), P<0.01)$
Table 2. Analysis of clinical and neurological data and the results of CT brain scan at the onset of SSICH in comparison with functional outcome of the acute period of disease

\begin{tabular}{llll}
\hline Indexes & $\begin{array}{l}\text { Unfavourable } \\
\text { functional outcome } \\
(\mathbf{n}=\mathbf{3 4})\end{array}$ & $\begin{array}{l}\text { Favourable } \\
\text { functional outcome } \\
(\mathbf{n}=\mathbf{4 8})\end{array}$ & $\mathbf{P}$ \\
\hline Age, years & $70.0(63.5-75.8)$ & $59.0(55.8-73.3)$ & 0.0101 \\
NIHSS score on the 1 ${ }^{\text {st }}$ day & $15.0(12.0-17.0)$ & $6.0(4.0-9.0)$ & $<0.0001$ \\
GCS score on the 1 $1^{\text {st }}$ day & $13.5(12.0-15.0)$ & $15.0(14.0-15.0)$ & 0.0023 \\
Lesion volume, ml & $15.5(5.4-32.3)$ & $7.2(1.8-17.1)$ & 0.0387 \\
Septum pellucidum displacement, $\mathrm{mm}$ & $3.5(0.3-7.0)$ & $0.0(0.0-3.0)$ & 0.0007 \\
Pineal gland displacement, mm & $2.5(0.3-5.0)$ & $0.0(0.0-2.3)$ & 0.0007 \\
\hline
\end{tabular}

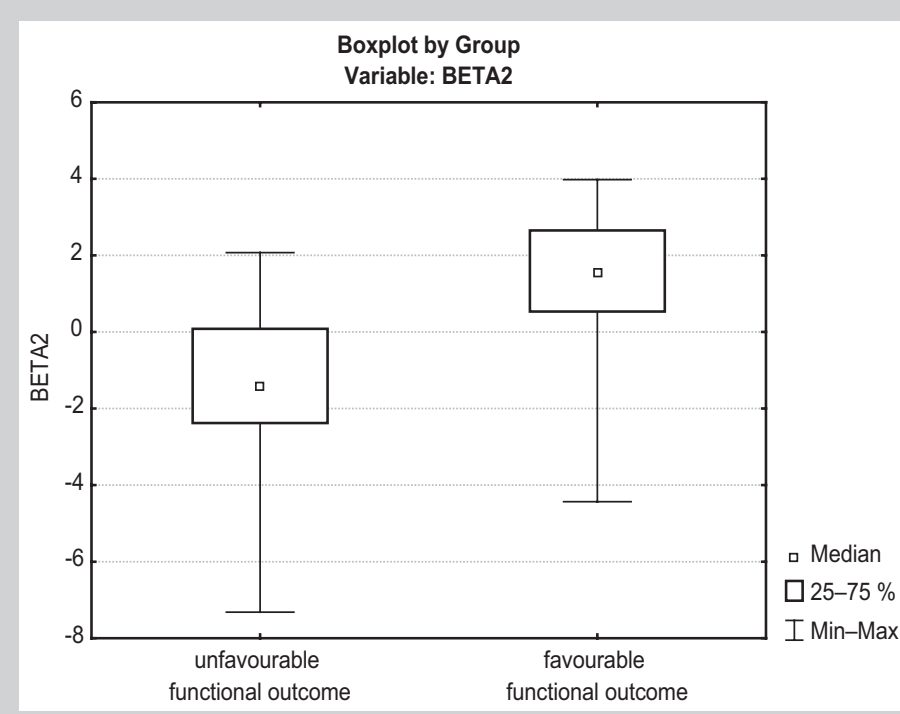

Fig. 3. $\beta 2$ index level in comparison with the functional outcome of SSICH acute period.

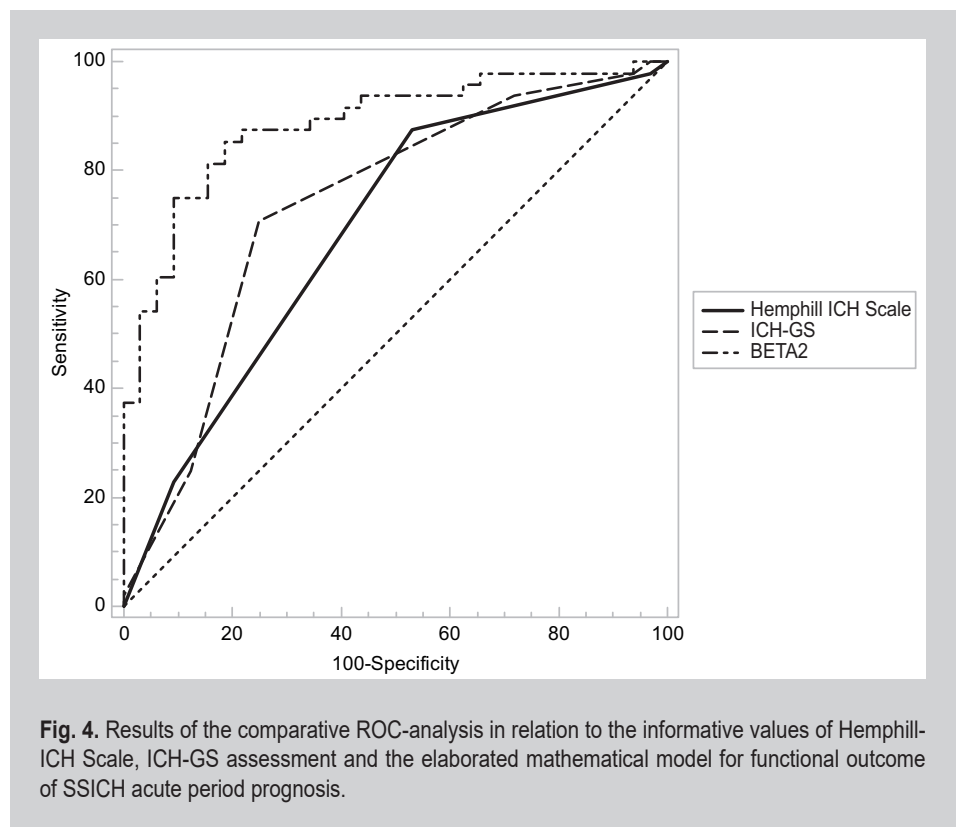

and ICH-GS (AUC $=0.75(0.64-0.84)$, while the index $\beta 2>0.175$ is the integral predictor of $\mathrm{mRS}$ score $\leq 3$ at the 21 st day of $\mathrm{SSICH}(\mathrm{Se}=85.4 \%$; $\mathrm{Sp}=82.4 \%$; accuracy of prediction $=80.5 \%$ ). 
The perspective for further research is the elaboration of integral clinical and neuroimaging criteria for prognosis of cerebral hemorrhagic supratentorial stroke with secondary intraventricular hemorrhage acute period outcome.

\section{References}

[1] Aiyagari, V. The clinical management of acute intracerebral hemorrhage. (2015). Expert Rev Neurother, 15(12), 1421-1432. doi: 10.158 6/14737175.2015.1113876

[2] Cai, X., \& Rosand, J. (2015). The Evaluation and Management of Adult Intracerebral Hemorrhage. Semin Neurol, 35(6), 638-645. doi: $10.1055 / \mathrm{s}-0035-1564687$.

[3] Camacho, E., LoPresti, M. A., Bruce, S., Lin, D., Abraham, M., Appelboom, G., et al. (2015). The role of age in intracerebral hemorrhages. J Clin Neurosci, 22(12), 1867-1870. doi: 10.1016/j.jocn.2015.04.020.

[4] Chen, G., Ping, L., Zhou, S., Liu, W., Liu, L., Zhang, D., et al. (2016). Early prediction of death in acute hypertensive intracerebral hemorrhage. Exp Ther Med, 11(1), 83-88. doi: 10.3892/etm.2015.2892.

[5] Godoy, D. A., Piñero, G. R., Koller, P., Masotti, L., \& Di Napoli, M. (2015). Steps to consider in the approach and management of critically ill patient with spontaneous intracerebral hemorrhage. World J Crit Care Med, 4(3), 213-229. doi: 10.5492/wjccm.v4.i3.213.

[6] Heeley, E., Anderson, C. S., Woodward, M., Arima, H., Robinson, T., Stapf, C., et al. (2015). Poor utility of grading scales in acute intracerebral hemorrhage: results from the INTERACT2 trial. Int J Stroke, 10(7), 1101-1107. doi: 10.1111/ijs.12518.

[7] Jolink, W. M., Klijn, C. J., Brouwers, P. J., Kappelle, L. J., \& Vaartjes, I. (2015). Time trends in incidence, case fatality, and mortality of intracerebral hemorrhage. Neurology, 85(15), 1318-1324. doi: 10.1212/ WNL.0000000000002015.

[8] Ozdinc, S., Unlu, E., Karakaya, Z., Turamanlar, O., Dogan, N., Isler, Y., et al. (2016). Prognostic value of perihematomal edema area at the initial ED presentation in patients with intracranial hematoma. Am J Emerg Med, 34(7), 1241-1246. doi: 10.1016/j.ajem.2016.03.048.

[9] Panchal, H. N., Shah, M. S., \& Shah, D. S. (2015). Intracerebral Hemorrhage Score and Volume as an Independent Predictor of Mortality in Primary Intracerebral Hemorrhage Patients. Indian J Surg, 77(Suppl 2), 302-304. doi: 10.1007/s12262-012-0803-2.

[10] Safatli, D. A., Günther, A., Schlattmann, P., Schwarz, F., Kalff, R., \& Ewald, C. (2016). Predictors of 30-day mortality in patients with spontaneous primary intracerebral hemorrhage. Surg Neurol Int, 7(Suppl 18), 510-517. doi: 10.4103/2152-7806.187493.

[11] Stein, M., Hamann, G. F., Misselwitz, B., Uhl, E., Kolodziej, M., \& Reinges, M. H. (2016). In-Hospital Mortality and Complication Rates in Surgically and Conservatively Treated Patients with Spontaneous Intracerebral Hemorrhage in Central Europe:A Population-Based Study. World Neurosurg, 88, 306-310. doi: 10.1016/j.wneu.2015.11.075.

\section{Information about author:}

Kuznietsov A. A., MD, PhD, Associate Professor, Department of Nervous Diseases, Zaporizhzhia State Medical University, Ukraine.

\section{Відомості про автора:}

Кузнєцов А. А., канА. меА. наук, Аоцент каф. нервових хвороб, Запорізький Аержавний меАичний університет, Україна.

\section{Сведения об авторе:}

Кузнецов А. А., канА. меА. наук, Аоцент каф. нервных болезней, Запорожский государственный медицинский университет, Украина.

Conflicts of Interest: author has no conflict of interest to declare. Конфмікт інтересів: віАсутній. 